\title{
Assessing water quality of rural water supply schemes as a measure of service delivery sustainability: A case study of WondoGenet district, Southern Ethiopia
}

\author{
Israel Deneke Haylamicheal ${ }^{1 \star}$ and Awdenegest Moges ${ }^{2}$ \\ ${ }^{1}$ Department of Chemistry, Hawassa University, Hawassa, Ethiopia. \\ ${ }^{2}$ Department of Biosystems and Environmental Engineering, Hawassa University, Hawassa, Ethiopia.
}

Accepted 24 April, 2012

\begin{abstract}
This study was conducted in WondoGenet district, Southern Ethiopia to assess the water quality of rural water supply schemes in relation to the sustainability of their service delivery. 28 functional water points were selected randomly, for their assessments. The assessments included sanitary surveillance of water points and water quality analyses. Water samples were analyzed for $\mathrm{pH}$, temperature, total dissolved solids, turbidity, total hardness, fecal and total coliform bacteria, fluoride, chloride, nitrate, manganese, and iron. The results obtained show that most of the 'user perceived' acceptable drinking water quality parameters were within the World Health Organization (WHO) guidelines for drinking water quality, based on aesthetic and taste considerations. Only one dug-well had marginally higher level of total hardness (that is, $220 \mathrm{mg} / \mathrm{l}$ of $\mathrm{CaCO}_{3}$ ), while four water points had higher turbidity ranging from 8.3 to 64 NTU when compared with the WHO guidelines. In all the sampled water points, the level of iron $(<0.009$ to $1.25 \mathrm{mg} / \mathrm{l})$, manganese $(0.10$ to $1.50 \mathrm{mg} / \mathrm{l})$, chloride $(0.80$ to $62.5 \mathrm{mg} / \mathrm{l})$, and nitrate $(0.90$ to $12.7 \mathrm{mg} / \mathrm{l})$ were within the WHO guidelines. Fluoride was also found to be below the WHO health based limit $(<1.5 \mathrm{mg} / \mathrm{l})$. However, majority (85.7\%) of the water points had detectable levels of total coliform bacteria (1 to $68 \mathrm{cfu}$ ). On the other hand, it was only in $25 \%$ of the water points that fecal coliform bacteria were detected (1 to $10 \mathrm{cfu}$ ). This shows that the bacteriological water quality is of concern as majority of the water points had detectable levels of coliform bacteria. Therefore, regular chlorination of water points, particularly dug wells, should continue. Besides, disinfection of water at the household level can be an added advantage.
\end{abstract}

Key words: Ethiopia, quality, rural, supply, sustainability, water.

\section{INTRODUCTION}

Water quality and the risk to waterborne diseases are critical public health concerns in many developing countries. Today, close to a billion people most living in the developing world do not have access to safe and adequate water (UNICEF/WHO, 2012). The World Health Organization (WHO) estimated that around $94 \%$ of the global diarrheal burden and $10 \%$ of the total disease burden are due to unsafe drinking water, inadequate sanitation, and poor hygienic practices (Fewtrell et al., 2007; Prüss-Üstün and Corvalán, 2006).

\footnotetext{
*Corresponding author. E-mail: israeld2@yahoo.com.
}

Thus, the provision of safe and adequate water contributes to better health and increased individual productivity. It is also recognized that there is significant relation between water supply and sanitation improvements and the potential for health and economic benefits (El-Fadel et al., 2003; Fewtrell et al., 2005; Peter, 2010; WHO/UNICEF, 2000). Accordingly, rural water supply schemes should deliver the expected service to users for a reasonable period of time in terms of quality, quantity, accessibility, coverage, affordability and continuity simply called sustainability (Harvey and Reed, 2004).

One of the most important factors that affect service delivery and the continued use of rural water supply 
schemes is the quality of water the schemes deliver to users (Brikke, 2002; Schouten and Moriarty, 2003). If water supply schemes fail to meet acceptable drinking water quality standards (that is, physical, chemical and/or bacteriological) people may stop using the scheme and resort to unsafe sources; and will be further exposed to acute and chronic illnesses (Karn and Harada, 2002). This will bring challenge in meeting the Millennium Development Goals (MDGs) of ensuring environmental sustainability, improving health and eradicating extreme poverty of the rural majority living in the developing world (United Nations, 2005).

The water supply coverage in Ethiopia has been one of the lowest in Sub-Saharan Africa (African Development Fund (ADF), 2005). The country's water supply subsector has been characterized by poor performance with a number of problems including unsustainability and unreliability of water supply services (MoWRD, 2006). To tackle these problems, the Government of Ethiopia issued the National Water Resources Management Policy in 1999 (MoWRD, 1999) and the Water Sector Strategy in 2001 (MoWRD, 2001) so as to increase and sustain the water supply services in both rural and urban areas and ultimately to ensure that every Ethiopian citizen has access to water of acceptable quality and sufficient quantity. In this regard, reports show that the total water supply coverage in the country is increasing: 2002 (22\%), 2007 (42.2\%) and 2008/2009 (59.5\%) (ADF, 2005; MoWRD, 2007, 2008). On the other hand, reports show that $33 \%$ of the rural water supply schemes in Ethiopia are estimated to be non-functional at any time (MoWRD, 2007).

Despite these problems, to scale-up the water supply coverage of the country and achieve a $100 \%$ water supply coverage in most of the regional states including the Southern Nations, Nationalities and Peoples Regional State (SNNPRS), the Government of Ethiopia adopted the Water Supply and Sanitation Universal Access Program (UAP) targeting to provide $15 \mathrm{~L}$ of safe water per person per day within a $1.5 \mathrm{~km}$ rural dwelling radius from the point of source by 2012 (MoWRD, 2006) (that is, 3 years before the Millennium Development Goals (MDGs) target). In this regard, the UAP emphasizes on groundwater development for drinking water supply in rural areas (MoWRD, 2006).

The quality of groundwater sources can be one challenge for scaling-up coverage and assuring continued use of water supply services. This is because of the fact that there are evidences of strong factors that may affect groundwater quality including rapid urbanization (Foppen, 2002; Al-kharabsheh, 1999) and land use practices (Gardner and Vogel, 2005), distance of onsite sanitation facilities from groundwater table (Bordalo and Savva-Bordalo, 2007; Odai and Dugbantey, 2003), level of groundwater (Papadakis et al, 2007) and natural rock characteristics (Rossiter et al., 2010; Tekle- Haimanot et al., 2006), among others.
Quite a number of studies have been conducted on drinking water quality supplies both in the urban and rural settings in countries such as Thailand (Kruawala et al., 2005), Zimbabwe (Hoko, 2005, 2008), Malawi (Pritchard et al., 2008; Mkandawire and Banda, 2009) and India (Suthar et al., 2009). On the other hand, studies in Ethiopia have focused mainly on technical functionality of water supply schemes (Admassu et al., 2003; Gebrehiwot, 2006; Jeths et al., 2009), equity and multiple uses of water infrastructure (RiPPLE, 2010) and linking water supply and sanitation (Hagos et al., 2008). Nevertheless, systematic studies on the relationship between rural drinking water supply schemes water quality and service sustainability has been lacking in the country. Therefore, this study was conducted to assess if the quality of drinking water from rural water supply schemes affects the sustainability of their use.

\section{MATERIALS AND METHODS}

\section{Study area}

The study was conducted in the SNNPRS, Sidama Zone, Wondo Genet Woreda (district) (Figure 1). Total area of the district is $226.45 \mathrm{~km}^{2}$ with a total projected population in 2010/2011 of 169 , 659 (FEDD, 2010). There were 14 Kebeles (villages) in the district of which three were under township administration, while the rest $(n=11)$ were exclusively rural. Out of the 14 villages, five were in the dega agro-ecology (temperate climate) with an altitude range between 2400 to 3000 m.a.s.I., and nine in the weyna-dega agroecology (semi-arid climate) of altitude between 1500 to 2400 m.a.s.l. The area also receives an annual rainfall of $1057 \mathrm{~mm}$. Groundwater from shallow aquifers is the main source for drinking water supply in the district. The water supply systems include springs, both on-spot and gravity piped distribution systems, and hand-dug and machine-dug wells fitted with hand-pump. People also use rivers and streams nearby for irrigation, cattle watering, washing clothes, and bathing.

\section{Study design and data collection}

Preliminary data on number villages, total population, and number water supply schemes by type and functionality were obtained from the district's water and energy office. During the study period (February 2011), there were a total of 170 water points including on-spot springs $(n=71)$, distribution spring stand-posts $(n=53)$, dug wells fitted with hand pump $(n=37)$ and rope pump $(n=9)$, of which75\% ( $n=127)$ were functional (Table 1). Randomly, 28 (32\%) functional water points composed of on-spot springs $(n=14)$ and dug wells fitted with hand pump $(n=14)$ were selected for sampling. Stand-posts from distribution spring systems were excluded from sampling mainly to avoid erroneous results that may emanate from additional contamination of the water in the distribution pipeline or reservoir. This is because analyzing water at the source (spring cape) or at the stand-post would only give a distorted result. Additionally, rope pump technologies were not included in the sampling because they were on a pilot trial stage and were not community managed.

Water samples were collected in four consecutive days from 11 to 14 February, 2011. A water quality analyst with a complete set of water quality analysis kit (Potalab ${ }^{\circledR}$ WAG-WE10010) was contracted 


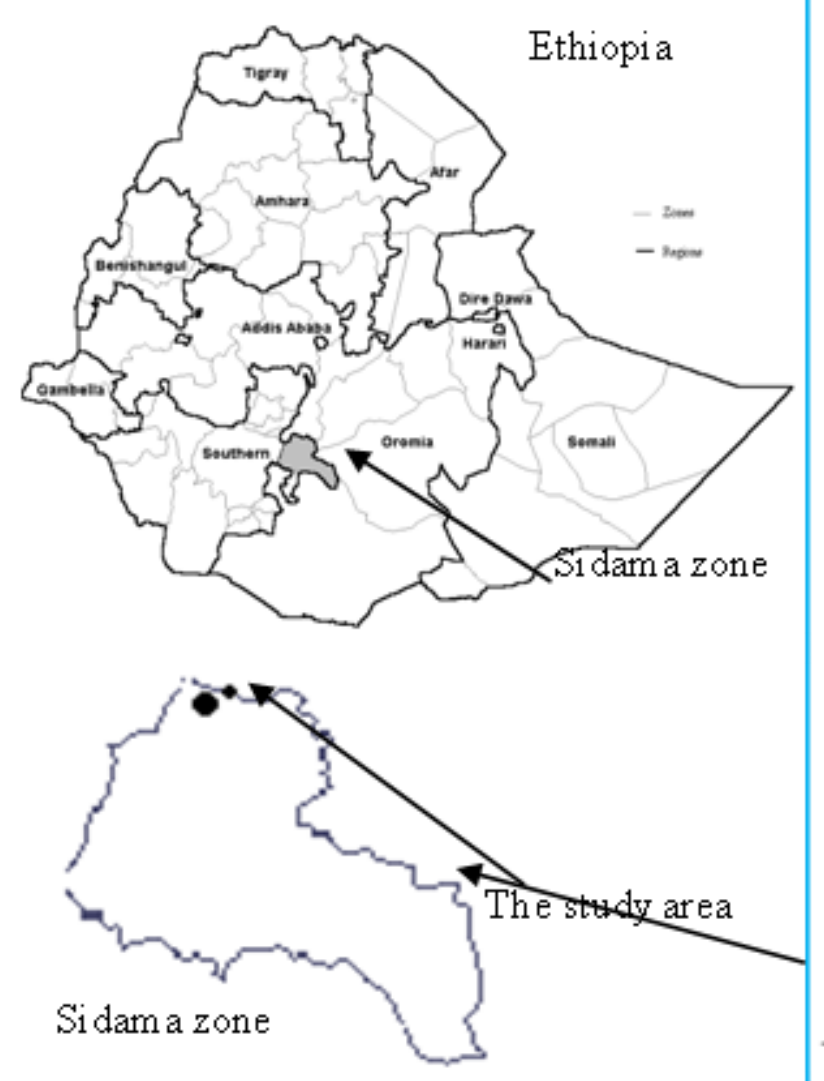

Figure 1. Map of the study area and the sampling locations.

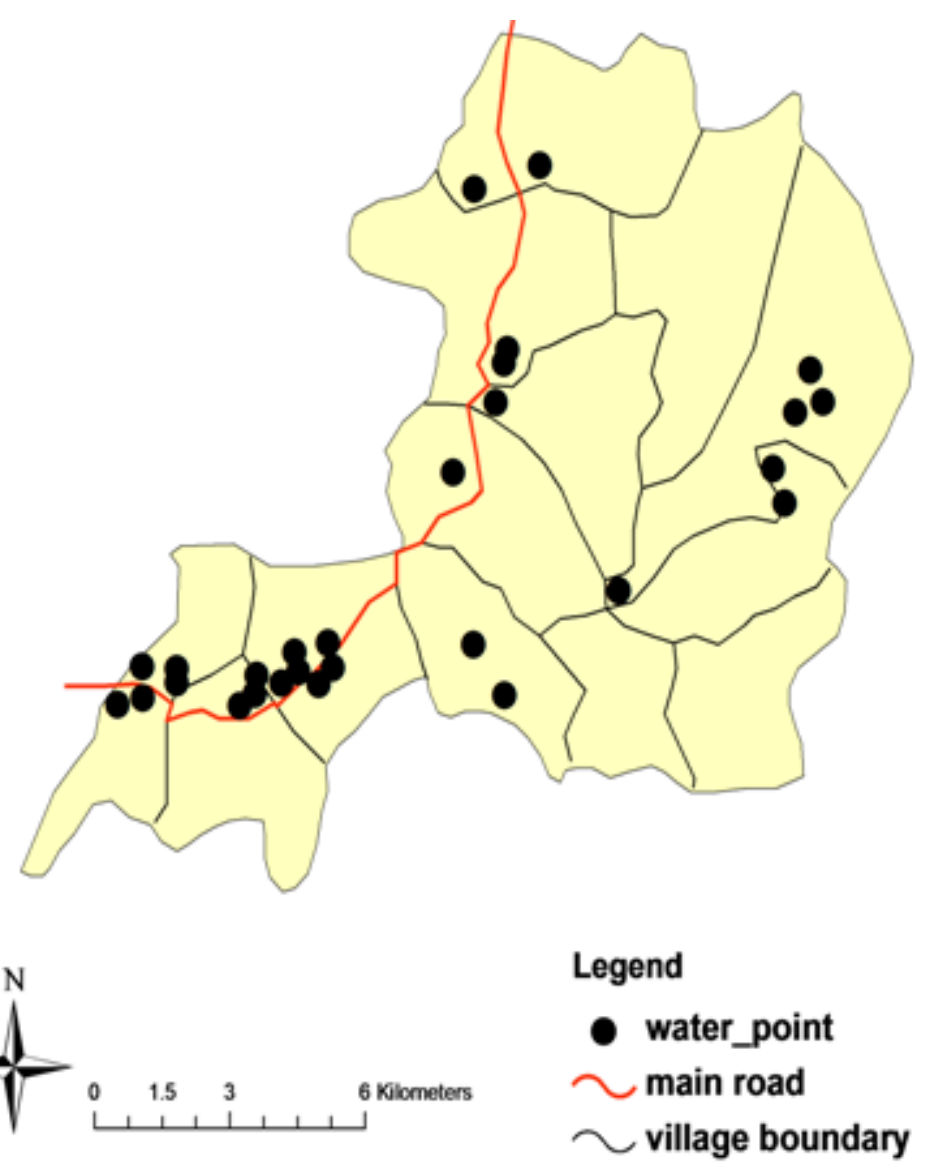

from the SNNPRS water and energy bureau water quality analysis laboratory. Water samples were both analyzed onsite and offsite for selected water quality parameters. Temperature, $\mathrm{pH}$, total dissolved solids (TDS), and turbidity were conducted onsite. Fecal and total coliform bacteria were processed onsite using membrane filter method and were transported to the regional laboratory. Total hardness, fluoride, chloride, nitrate, manganese and iron were analyzed in the laboratory after the samples were properly transported using a pre-cleaned $1 \mathrm{~L}$ plastic containers in an ice box.

Generally, sample container preparation, storage and transport procedures followed the recommendations of Standard Methods for the Examination of Water and Wastewater manual (APHA, 1998). Analysis of fluoride, chloride, nitrate, manganese and iron was carried out using $\mathrm{HACH}$ DR 500 instrument (UV-visible spectrophotometer) in accord with the procedures of the $\mathrm{HACH}$ manual $(\mathrm{HACH}, 2010)$. In addition, total hardness was determined using titration method. Since the samples were collected in a relatively dry season, the result does not explain seasonal changes in water quality.

The data collection also included sanitary survey of the water points using a standardized checklist. The checklist was completed by interviewing water committees, water users nearby and personal observation of the water points. It included main points such as general location information, aspects of the water point (that is, type, technology used, year of construction, funding agency, served population, functionality, and discharge rate) and sanitary surveillance. Data were analyzed using Statistical Package for Social Sciences (SPSS) 14.0 statistical package and MS Excel.
Data were checked for normality, and median was used instead of mean where data were not normally distributed.

\section{RESULTS AND DISCUSSION}

\section{Water points}

The sampled water points were found in 10 villages (Table 2) and were expected to serve for a total of 10,450 people $(6.2 \%$ of the total population in the district) based on Government standard (that is, hand-dug well: 250 users; machine-dug well: 500 users; and on-spot spring: 300 users) (MoWRD, 2006).

Regarding water discharge (Table 3 ), on on-spot springs generate a median of $0.13 \mathrm{~L}$ of water per second. Similarly, machine-dug wells and hand-dug wells generate a median of 0.31 and $0.30 \mathrm{~L}$ of water per second, respectively. This shows that all the water points had discharge rate above the Government minimum for the design population.

Of the 28 water points, only $35.7 \% \quad(n=10)$ were developed by the Government. The rest (64.3\%) were developed by various NGOs. In addition, $42.9 \%$ of the 
Table 1. Water points by scheme type and functionality.

\begin{tabular}{lcc}
\hline Water point & Functional & Non-functional \\
\hline Dug wells fitted with pump (hand pump and rope pump) & 30 & 16 \\
On-spot spring & 60 & 11 \\
Distribution Spring stand-post & 37 & 16 \\
Total & 127 & 43 \\
\hline
\end{tabular}

Table 2. Location, number and type of water points investigated.

\begin{tabular}{clcl}
\hline S/N & Village & Number of water point $(\mathbf{n})$ & Water point type \\
\hline 1 & Abaye & 3 & On-spot springs \\
2 & Aruma & 3 & Dug wells fitted with Afridev hand pump \\
3 & Babo Chorora & 3 & On-spot springs \\
4 & Baja Fabrica & 2 & On-spot springs \\
5 & Baja Gamecho & 1 & On-spot springs \\
6 & Chuko & 1 & On-spot springs \\
7 & Edo & 6 & Dug wells fitted with Afridev hand pump \\
8 & Gike Gina & 2 & On-spot springs \\
9 & Wosha Soyama & 2 & On-spot springs \\
10 & Yuwo & 5 & Dug wells fitted with Afridev hand pump \\
\hline
\end{tabular}

Table 3. Water discharge rate $(I / s)$.

\begin{tabular}{lccc}
\hline Water sample (N=28) & On-spot spring & Machine-dug well & Hand-dug well \\
\hline $\mathrm{n}$ & 14 & 11 & 3 \\
Range & 0.99 & 0.13 & 0.23 \\
Minimum & 0.01 & 0.20 & 0.10 \\
Maximum & 1.00 & 0.33 & 0.33 \\
Median & 0.13 & 0.31 & 0.30 \\
Government standard (Minimum rate) & 0.10 & 0.26 & 0.13 \\
\hline
\end{tabular}

water points had served for more than twenty years since construction, while $25 \%$ served for more than ten years. It was only $21.4 \%$ of the water points, all being on-spot springs, which served only for a year. This shows that quite a good number of the water points have been serving beyond their design period (that is, 20 years).

\section{Sanitary inspection}

\section{Source protection and treatment}

Chemical treatment such as chlorination of water points at the source is one effective method to remove pathogens from water and reduce the transmission of waterborne diseases (Smith and Scott, 2002). In this regard, all the dug wells investigated were reported to be chlorinated fairly once in every three months. The awareness for regular chlorination of the dug wells began after the cholera epidemic in 2007/2008 in parts of the country. However, since on-sport springs are running waters (that is, continuously out flowing as opposed to standing waters), chlorination cannot not be practiced. Therefore, all on-spot springs are skipped from chlorination.

\section{Factors affecting water quality at source}

Distance of contaminating sources such as pit latrines to water points has been an important estimator in indicating the possible source of bacterial contamination of groundwater. In most cases, it is advisable to construct latrine at a minimum radius of $30 \mathrm{~m}$ down-slope of the water point $(\mathrm{MoH}, 2004)$.

In this study, only four (14\%) of the water points were 
found to be too close ( $<30 \mathrm{~m}$ radius) to latrines increasing the risk of fecal contamination. This is because studies have identified pit latrines as sources of bacteria to groundwater (Dzwairo et al., 2006). On the other hand, in $10(36 \%)$ of the water points people were observed bathing and washing clothes near or around the water points. However, it was only in six $(21 \%)$ of the water points that stagnant water was observed. $64 \%(n=18)$ of the water points were not fenced at all, which could have prevented animals from reaching the water points and might reduce the possibility of contamination of the water points by animals. Additionally, none of the water points had guards. And, it was only in one of the on-spot springs that the spring cape was not well covered.

Seasonal variations of water quality especially turbidity is common when the groundwater table is relatively close to the surface. In the study, users in $53.6 \%$ of the water points reported that the water at the water points becomes turbid after heavy rain indicating easy infiltration of runoff to the groundwater and increased risk of groundwater contamination. Similar result was also reported in Guinea-Bissau (Bordalo and Savva-Bordalo, 2007).

Users in six (21\%) of the water points complained that the water had taste and/or odor problems. Similar taste complaints were reported by Hoko (2008) from boreholes in Zimbabwe. Besides, users in four water points (all hand pumps) complained that their children have experienced dental fluorosis because of high fluoride content in the water. However, water quality analysis showed that the fluoride content in these water points was within the World Health Organization (WHO) drinking water guidelines; $1.5 \mathrm{mg} / \mathrm{l}$ (WHO, 2004). In one water point, users complained observing worms in their water and suggested that it may be because of the presence of a pit latrine uphill near the water point.

\section{Water quality analyses}

\section{Acceptability aspects}

In the study, five 'user perceived' acceptable drinking water quality parameters (that is, total hardness, total dissolved solids (TDS), $\mathrm{pH}$, turbidity and temperature), that were considered to have an effect on the acceptability of water for use were determined. Generally, the results showed that most of the measured values of these parameters were within the WHO guidelines for drinking water quality (WHO, 2004) based on aesthetic and taste considerations (Table 4).

The $\mathrm{pH}$ values of $18 \%(\mathrm{n}=5)$ of the water points (all onspot springs) were between 5.7 and 6.4. Although $\mathrm{pH}$ affects the taste of water (Hoko, 2008), no complaint regarding sourness (acidity) was reported by users during the sanitary survey. All the dug wells (depth range: 8 to $14 \mathrm{~m})$ fitted with hand-pumps $(\mathrm{n}=14)$ had $\mathrm{pH}$ values within the range of 6.6 to 7.8 , which is within the WHO recommended limit for taste considerations. Temperature in these water points ranged from 18.2 to $30.3^{\circ} \mathrm{C}$. Although no guideline is set for it, higher temperatures are not recommended mainly because they make drinking difficult. Regarding hardness, one dug well indicated marginally higher level of total hardness (that is, $220 \mathrm{mg} / \mathrm{l}$ as $\left.\mathrm{CaCO}_{3}\right)$ while the rest $(\mathrm{n}=27)$ were within the WHO (2004) guidelines range depicting lower levels of calcium and magnesium in the groundwater.

Four (14.3\%) water points (on-spot springs and dug wells, two each) were indicated to have higher turbidity ranging from 8.3 to 64 NTU compared to the WHO (2004) guideline, while TDS was found to be within the WHO recommended range based on taste considerations in all the cases. In this regard, a Spearman's rank correlation test also confirmed that there is no significant correlation between TDS and turbidity $(P=0.08)$ changes across water points. It is worth noting that these values are deemed to vary based on seasonal changes. This is because of the fact that the study was conducted in a relatively dry season, thus in a wet season some values may be lower due to dilution while others higher as a result of dissolution, dissociation, infiltration and/or other physical and chemical processes.

\section{Chemical and bacteriological aspects}

Table 5 shows results of chemical and bacteriological analyses. In all the sampled water points, $(n=28)$ the level of iron $(<0.009$ to $1.25 \mathrm{mg} / \mathrm{l})$, manganese $(0.10$ to 1.50 $\mathrm{mg} / \mathrm{l})$, chloride $(0.80$ to $62.5 \mathrm{mg} / \mathrm{l})$ and nitrate $(0.90$ to $12.7 \mathrm{mg} / \mathrm{l})$ were within the WHO guidelines for drinking water quality (WHO, 2004).

Fluoride was also found to be below the WHO health based limit (that is, $1.5 \mathrm{mg} / \mathrm{l}$ ), despite complaints by users regarding dental fluorosis on children in four water points (all dug wells). In this regard, reports indicate that sometimes fluoride levels between 0.9 and $1.2 \mathrm{mg} / \mathrm{l}$ may cause mild dental fluorosis (WHO, 2004). Others also set an optimum drinking water fluoride level of 0.5 to 0.65 $\mathrm{mg} / \mathrm{l}$ in fluoride endemic areas (Viswanathan et al., 2009).

Since part of the study area (including the four water points) lies in fluoride endemic region-Rift Valley region of Ethiopia, total daily fluoride intake from different sources should also be considered to justify for the dental fluorosis. The Rift Valley region of Ethiopia is characterized by higher level of groundwater fluoride. For instance, Tekle-Haimanot et al. (2006) reported that out of 668 wells (deep and shallow) analyzed for fluoride level in the Rift Valley region of Ethiopia, $44.5 \%$ of the wells had values above $1.5 \mathrm{mg} / \mathrm{l}$.

The WHO guidelines for drinking-water quality (WHO, 2004) recommends that for all waters intended for drinking no total and/or fecal coliform bacteria should be detected in any $100 \mathrm{ml}$ water sample. In this regard, 
Table 4. Measured acceptability parameters for drinking water quality.

\begin{tabular}{lccccc}
\hline $\begin{array}{l}\text { Number of sample } \\
\text { (N=28) }\end{array}$ & $\begin{array}{c}\text { Total hardness } \\
\left(\mathbf{m g} / \mathbf{l} \text { as } \mathbf{C a C O}_{3}\right)\end{array}$ & TDS $(\mathbf{m g} / \mathbf{l})$ & $\mathbf{p H}$ & Turbidity (NTU) & Temperature $\left({ }^{\circ} \mathbf{C}\right)$ \\
\hline Average & 85.7 & 246.8 & 6.8 & 6.2 & 24.3 \\
Standard deviation & 47.5 & 248.6 & 0.5 & 13.8 & 2.9 \\
Minimum & 30.0 & 4.8 & 5.7 & 0.0 & 18.2 \\
Maximum & 220.0 & 921.5 & 7.8 & 64.0 & 30.3 \\
Median & 74.0 & 158.3 & 6.8 & 2.0 & 24.4 \\
WHO guideline (2004) & $100-200$ & $<1200$ & $6.5-8.5$ & $<5$ & n.g.v. \\
\hline
\end{tabular}

TDS: total dissolved solid; NTU: nephelometric turbidity unit; n.g.v.: no guideline value.

Table 5. Results of chemical and bacteriological analyses.

\begin{tabular}{lccccccc}
\hline $\begin{array}{l}\text { Number of sample } \\
\text { (N=28) }\end{array}$ & $\begin{array}{c}\mathbf{F e}^{2+} \\
(\mathbf{m g} / \mathbf{l})\end{array}$ & $\begin{array}{c}\mathbf{M n}^{2+} \\
(\mathbf{m g} / \mathbf{l})\end{array}$ & $\begin{array}{c}\mathrm{Cl}^{-} \\
(\mathbf{m g} / \mathbf{l})\end{array}$ & $\begin{array}{c}\mathbf{F}^{-} \\
(\mathbf{m g} / \mathbf{l})\end{array}$ & $\begin{array}{c}\mathbf{N O}_{3}^{-} \\
(\mathbf{m g} / \mathbf{l})\end{array}$ & $\begin{array}{c}\text { Total coliform } \\
(\mathbf{c f u} / \mathbf{1 0 0} \mathbf{~ m l})\end{array}$ & $\begin{array}{c}\text { Fecal coliform } \\
(\mathbf{c f u} / \mathbf{1 0 0} \mathbf{~ m l})\end{array}$ \\
\hline Average & 0.15 & 0.38 & 10.56 & 0.50 & 4.21 & 11 & 1 \\
Standard deviation & 0.26 & 0.34 & 13.12 & 0.39 & 3.15 & 15 & 3 \\
Minimum & $<0.009$ & 0.10 & 0.80 & $<0.02$ & 0.90 & 0 & 0 \\
Maximum & 1.25 & 1.50 & 62.5 & 1.34 & 12.7 & 68 & 10 \\
Median & 0.06 & 0.30 & 6.25 & 0.44 & 3.05 & 6 & 0 \\
WHO guideline (2004) & $<0.3^{\mathrm{c}}$ & $0.4^{\mathrm{b}}$ & $<250^{\mathrm{a}}$ & $1.5^{\mathrm{b}}$ & $50^{\mathrm{b}}$ & 0 & 0 \\
\hline
\end{tabular}

a : Taste detection; ${ }^{\mathrm{b}}$ : Health based standard; ${ }^{\mathrm{c}}$ : Aesthetic consideration; cfu: coliform forming units.

majority $(85.7 \%)$ the water points had detectable levels of total coliform bacteria (1 to $68 \mathrm{cfu}$ ). However, it was only in $25 \%$ of the water points that fecal coliform bacteria were detected ( 1 to $10 \mathrm{cfu}$ ) (Table 5). A similar study in Malawi identified that about $80 \%$ of water samples collected from wells fitted with hand-pumps had detectable levels of coliform bacteria (Pritchard et al., 2008). Meanwhile, another study in Brazil indicated the presence of detectable levels of fecal coliform bacteria in untreated drinking water samples collected from springs $(48 \% ; \mathrm{N}=96)$ and private wells $(15 \% ; \mathrm{N}=350)$ (Nogueira et al., 2003).

In this study, only three water points were found to be free from both types of coliform bacteria. The result indicated that bacteriological water quality is a concern in this area. It must be clear that the provision of water services must result in health improvements to users as an ultimate goal. However, when this goal is compromised and user's health is affected, they commonly resort to their traditional unsafe sources or travel longer distances to find other safe water sources.

\section{Conclusion}

People in the study area largely depend on improved water sources developed from groundwater for drinking and other domestic activities. Although chlorination of the water points might have helped the reduction of pathogens, design problems and other improper activities around the water points might be the cause for higher levels of coliform bacteria.

The taste and odor complaints may lead users to an immediate rejection of water points with the possibility of ultimate abandonment or to the fact that people stop using the water points for drinking purposes. Besides, users complaints of dental fluorosis cases in few of the water points is something to be further investigated as the water quality analysis result did not support their proposition (that is, fluoride level $<1.5 \mathrm{mg} / \mathrm{l}$ in all water points). Probably, the dental fluorosis cases may be caused by various intake sources and/or higher duration of exposure. Acceptability aspects of drinking water quality such as $\mathrm{pH}$, temperature, turbidity, TDS and total hardness were generally good. The presence of lower $\mathrm{pH}$ and higher turbidity and hardness levels in few of the water points may affect their continued use. On the other hand, the level of iron, chloride, nitrate, and manganese was generally good all within the WHO guidelines for health and aesthetic considerations. Bacteriological quality is a concern as $85.7 \%$ of the water points had detectable levels of coliform bacteria. The presence of coliform bacteria may be as a result of poor capping of spring structures and absence of source protection measures, and may be due to shallow groundwater tables and in appropriate activities around water points 
in the case of dug wells.

In general, to sustain service delivery of water points by maintaining good quality water, scheme/water point construction should follow proper planning complemented by design treatments such as locating water points at reasonable distance from potentially contaminating sources such as pit latrines and runoff and proper construction of spring capping structure. Moreover, protection of water points through natural vegetation barriers, regular chlorination of water points, preventing water stagnation around water points and fencing, and preventing bathing and washing clothes around to prevent contamination of ground water will help maintain and improve water quality. Besides, disinfection of water at household level can be an added advantage.

\section{ACKNOWLEDGEMENTS}

This project (no. 6223-150) was supported by the Hawassa University regular research fund of 2010/2011. Water users and experts from the SNNPRS bureau of water and energy who provided us with information and participated in data collection are greatly acknowledged.

\section{REFERENCES}

ADF (African Development Fund) (2005). Rural water supply and sanitation program appraisal report: Ethiopia. Infrastructure department, North, East and South, ONIN. ADF.

Admassu M, Kumie A, Fantahun M (2003). Sustainability of drinking water supply projects in rural of North Gondar, Ethiopia. Ethiop. J. Health Dev., 3:221-229.

Al-kharabsheh A (1999). Influence of urbanization on water quality at Wadi Kufaranja basin (Jordan). J. Arid. Environ., 43:79-89.

APHA (American Public Health Association) (1998). Standard methods for the examination of water and wastewater (20th ed.). Washington DC.

Bordalo AA, Savva-Bordalo J (2007). The quest for safe drinking water: An example from Guinea-Bissau (West Africa). Water Res., 41:29782986.

Brikke $F$ (2002). Operation and maintenance of rural water supply and sanitation systems: A training package for managers and planners. World Health Organization, Geneva.

Dzwairo B, Hoko Z, Love D, Guzha E (2006). Assessment of the impacts of pit latrines on groundwater quality in rural areas: A case study from Marondera district, Zimbabwe. Phys. Chem. Earth, 31:779-788.

El-Fadel M, Maroun R, Semerjian L, Harajli H (2003). A Health-based socio-economic assessment of drinking water quality: the case of Lebanon. Manage. Environ. Qual., 14(3):353-368.

FEDD (Finance and Economic Development Department) (2010). Sidama zone socio-economic profile 2010/11 (2002 E.C). Sidama zone finance and economic development department, development of data collection and dissemination main process, Hawassa, Ethiopia.

Fewtrell L, Kaufmann RB, Kay D, Enanoria W, Haller L, Colford Jr JM (2005). Water, sanitation, and hygiene interventions to reduce diarrhea in less developed countries: a systematic review and metaanalysis. Lancet Infect. Dis., 5:42-52.

Fewtrell L, Prüss-Üstün A, Bos R, Gore F, Bartram J (2007). Water, sanitation and hygiene: quantifying the health impact at national and local levels in countries with incomplete water supply and sanitation coverage. WHO, Geneva.

Foppen J (2002). Impact of high-strength wastewater infiltration on groundwater quality and drinking water supply: The case of Sana'a, Yemen. J. Hydrol., 263:198-216.

Gardner KK, Vogel MR (2005). Predicting ground water nitrate concentration from land use. Ground Water, 43(3): 343-352.

Gebrehiwot M (2006). An assessment of challenges of sustainable rural water supply: The case of Ofla woreda in Tigray Region. MSc thesis, School of graduate studies, regional and local development study, Addis Ababa University, Addis Ababa, Ethiopia.

$\mathrm{HACH}$ (2010). DR/2010 spectrophotometer instrument manual. $\mathrm{HACH}$ Company, Colorado, USA.

Hagos F, Boelee E, Awulachew BS, Slaymaker T, Tucker J, Ludi E (2008).Water supply and sanitation (WSS) and Poverty: Micro-level linkages in Ethiopia. RiPPLE working paper 8, Ripple, Ethiopia.

Harvey P, Reed RA (2004). Rural water supply in Africa: Building blocks for hand-pump sustainability. Water, engineering and development center, Loughborough University, UK.

Hoko Z (2005). An assessment of the water quality of drinking water in rural districts in Zimbabwe. The case of Gokwe South, Nkayi, Lupane, and Mwenezi districts. Phys. Chem. Earth, 30: 859-866.

Hoko Z (2008). An assessment of quality of water from boreholes in Bindura District, Zimbabwe. Phys. Chem. Earth, 33: 824-828.

Jeths M, Haylamicheal ID, Abebe HA (2009). The sustainability of water supply schemes in Mirab Abaya and Alaba Special Woreda, SNNPRS, Ethiopia. Water, sanitation and hygiene: Sustainable development and multisectoral approaches; 34th WEDC International Conference, Addis Ababa, Ethiopia.

Karn SK, Harada H (2002). Field survey on water supply, sanitation and associated health impacts in urban poor communities - a case from Mumbai City, India. Water Sci. Technol., 46(11-12): 269-275.

Kruawala K, Sacherb F, Wernerc A, Mqllerc J, Knepperc PT (2005). Chemical water quality in Thailand and its impacts on the drinking water production in Thailand. Sci. Total Environ., 340: 57-70.

Mkandawire T, Banda E (2009). Assessment of drinking water quality of Mtopwa village in Bangwe Township, Blantyre. Desalination, 248:557-561.

$\mathrm{MoH}$ (Ministry of Health) (2004). Water supply safety measures extension package. The Federal Democratic Republic of Ethiopia ministry of health. Addis Ababa, Ethiopia.

MoWRD (Ministry of Water Resources Development) (1999). Ethiopian Water Resources Management Policy. MoWRD, Addis Ababa, Ethiopia.

MoWRD (Ministry of Water Resources Development) (2001). Ethiopian water sector strategy. MoWRD, Addis Ababa, Ethiopia.

MoWRD (Ministry of Water Resources Development) (2006). Federal Democratic Republic of Ethiopia ministry of water resources, universal access program for water supply and sanitation services 2006-2012, international calendar 1999-2005 Ethiopian calendar Part I-Rural. MoWRD, Addis Ababa, Ethiopia.

MoWRD (Ministry of Water Resources Development) (2007). Water sector development program (WSDP) reports, Addis Ababa, Ethiopia.

MoWRD (Ministry of Water Resources Development) (2008). Water sector development: PASDEP 2008/09 budge year performance report (Amharic version). MoWRD, Addis Ababa, Ethiopia.

Nogueira G, Nakamura VC, Tognim CBM, Filho AAB, Filho PDB (2003). Microbiological quality of drinking water of urban and rural communities, Brazil. Rev. Saúde Pública. 37(2): 232-236.

Odai NS, Dugbantey DD (2003). Towards pollution reduction in periurban water supply: A case study of Ashanti region in Ghana. Diffuse pollution conference poster papers, Dublin, 14: 72-75.

Peter G (2010). Impact of rural water projects on hygienic behaviour in Swaziland. Phys. Chem. Earth, 35: 772-779.

Pritchard M, Mkandawire T, O'Neill GJ (2008). Assessment of groundwater quality in shallow wells within the southern districts of Malawi. Phys. Chem. Earth, 33: 812-823.

Prüss-Üstün A, Corvalán C (2006). Preventing disease through health environments. Towards an estimate of the environmental burden of disease. WHO, Geneva.

RiPPLE (Research-inspired Policy and Practice Learning in Ethiopia) (2010). Equitable water for multiple uses: A case from SNNPR. Working paper summary, RiPPLE program, Ethiopia.

Rossiter HMA, Owusu PA, Awuah E, MacDonald AM, Schäfer AI

(2010). Chemical drinking water quality in Ghana: Water costs and 
scope for advanced treatment. Sci. Total Environ., 408, 2378-2386.

Smith GP, Scott SJ (2002). Dictionary of water and waste management. IWA publishing, London.

Suthar S, Bishnoi P, Singh S, Mutiyar PK, Nema AK, Patil NS (2009). Nitrate contamination in groundwater of some rural areas of Rajasthan, India. J. Hazard. Mater.,171: 189-199.

Schouten T, Moriarty P (2003). From System to Service. IRC International Water and Sanitation Centre and ITDG, The Hague, Netherlands.

Tekle-Haimanot R, Melaku Z, Kloos H, Reimann C, Fantaye W, Zerihun $\mathrm{L}$, Bjorvatn $\mathrm{K}$ (2006). The geographic distribution of fluoride in surface and groundwater in Ethiopia with an emphasis on the Rift Valley. Sci. Total Environ., 367:182-190.

UNICEF/WHO (2012). Progress on drinking water and sanitation: 2012 update. WHO/UNICEF Joint Monitoring Program for water supply and sanitation. UNICEF, New York. Available at: ttp://www.wssinfo.org/fileadmin/user_upload/resources/JMP-report2012-en.pdf (Accessed on: March 30, 2012).
United Nations (2005). The millennium development goals report 2005. UN, New York.

Viswanathan G, Jaswanth A, Gopalakrishnan S, Siva llango S, Aditya G (2009). Determining the optimal fluoride concentration in drinking water for fluoride endemic regions in South India. Sci. Total Environ., 407: 5298-5307.

WHO (2004). Guidelines for drinking-water quality (3rd ed.). Vol. 1, recommendations. World Health Organization, Geneva.

WHO/UNICEF (2000). Global water supply and sanitation assessment report. The WHO/UNICEF Joint Monitoring Program for water supply and sanitation. WHO/UNICEF, Geneva. 